\title{
DEVELOPMENT OF BILAYER TABLETS OF LOSARTAN POTASSIUM AND METFORMIN HYDROCHLORIDE LAYER USING NATURAL GUMS AS POLYMERS
}

\author{
RAJYALAKSHMI KADIYAM*, KAVYA R \\ Department of Pharmaceutics, Bapatla College of Pharmacy, Bapatla, Andhra Pradesh, India. Email: rajimanohar3529@gmail.com
}

Received: 01 April 2020, Revised and Accepted: 11 May 2020

ABSTRACT

Objective: The aim of this research work was to develop and evaluate a bilayer formulation of losartan potassium and metformin hydrochloride for the treatment of diabetic patients with hypertension. In the present study, losartan potassium as immediate-release (IR) layer and metformin hydrochloride as a sustained-release (SR) layer were selected.

Methods: The polymers selected were fenugreek gum, sweet potato starch, and ispaghula gum as natural disintegrants for IR layer and guar gum, xanthan gum, and pectin for SR layer. Bilayer tablets were developed by employing the two layers.

Results: For IR layer, L4 formulation with 5\% ispaghula gum as natural disintegrant showed 98.94\% drug release was selected as an optimized layer. For sustained layer, F2 formulation with 18.75\% guar gum as drug retardant showed $97.17 \%$ drug release was selected as optimized layer. Optimized formulation followed zero-order kinetics. When the release data was plotted into Higuchi and Korsmeyer-Peppas equations, then it was confirmed that the optimized formulation exhibited a Fickian diffusion type drug release.

Conclusion: Tablets prepared with 5\% ispaghula gum and $18.75 \%$ guar gums as drug retardants were found to be useful for bilayer tablet formulation with desired drug release characteristics.

Keywords: Sustained release layer, Immediate-release layer, Losartan potassium and metformin hydrochloride layer.

(C) 2020 The Authors. Published by Innovare Academic Sciences Pvt Ltd. This is an open access article under the CC BY license (http://creativecommons. org/licenses/by/4. 0/) DOI: http://dx.doi.org/10.22159/ajpcr.2020.v13i7.37797

\section{INTRODUCTION}

Oral ingestion has been the most convenient and commonly employed route of drug delivery due to its ease of administration. The design of a modified release drug product is usually intended to optimize a therapeutic regimen by providing slow and continuous delivery over the entire dosing interval [1-3]. Bilayer tablet is the novel drug delivery system where a combination of two or more drugs in a single unit having different release profiles improves patient compliance; prolongs the drug action resulting in effective therapy along with better control of plasma drug levels. Bilayer tablets [4-6] can be the primary option to avoid chemical incompatibilities between active pharmaceutical ingredients by physical separation and to enable the development of different drug release profiles. Immediate release (IR) dosage forms are those for which $\geq 85 \%$ of the labeled amount dissolves within $30 \mathrm{~min}$. Sustained-release (SR) drug delivery systems can be defined as any dosage form that prolongs the therapeutic activity of the drug by continuously releasing medication over an extended period of time. The approach decreases the pill burden on the patient. Treat different ailments in the same patient (co-morbidity) at the same time with only one tablet. Bilayer tablets also allow for synergistic combinations. These tablets will also provide elegance to the product.

The drug losartan potassium [7-9] was selected for IR layer. As the drug undergoes extensive first-pass metabolism $(\mathrm{F}=0.33)$ that can be overcome by formulating the drug as an IR layer because the entire drug releases in the region of the stomach and absorbs completely before entering into liver. The drug also has a biological half-life of 6-9 h that suits the drug for IR part. For SR layer, metformin hydrochloride layer $(\mathrm{HCl})$ [10-12] is selected because of having large dose $(500 \mathrm{mg})$ and $\mathrm{t}_{1 / 2}$

of around $2 \mathrm{~h}$ where frequent administration of drugs can be minimized. Hence, this work was aimed to release losartan potassium within 30 min and metformin $\mathrm{HCl}$ for a period of $10 \mathrm{~h}$.

In this work, various natural polymers, namely, pectin, sweet potato starch, fenugreek gum, and ispaghula gum, were employed for the preparation of bilayer tablets. These polymers are natural origin, bio-processed, and biodegradable, whereas synthetic polymers derived from chemical reactions are found to be hard and are not biodegradable. These natural polymers have antioxidant and anti-aging properties compared to synthetic polymers. The natural polymer pectin that is extracted from orange peel has antioxidant, anti-diabetic, and reduces gastroesophageal reflux disease. Fenugreek gum has multiple uses such as treatment of obesity, hypertension, and reduction blood glucose levels. Ispaghula gum can be employed in the treatment of bladder problems and hypertension and can be employed for skin irritations. These polymers have super disintegrating properties (pectin, fenugreek gum, and ispaghula gum) as well as SR characteristics (xanthan gum and guar gum).

\section{MATERIALS AND METHODS}

\section{Materials}

Losartan potassium was obtained as a gift sample from Hetero Labs, Hyderabad. Metformin $\mathrm{HCl}$ was obtained from Apogen Remedies, Bapatla. All the remaining chemicals used were of analytical grade.

\section{Methods}

\section{Preparation of gums}

Extraction of pectin

One hundred grams of orange peels were mixed with $500 \mathrm{ml}$ water and $2.5 \mathrm{ml} \mathrm{HCl}$. Boiled for $45 \mathrm{~min}$ and filtered. The filtrate was washed with $250 \mathrm{ml}$ of boiled water. Later, it was cooled to $25^{\circ} \mathrm{C}$. Extract was precipitated by adding $200 \mathrm{ml} 95 \%$ ethanol. It was subjected to thorough stirring and left it for 30 min to allow pectin float on the surface. Extracted pectin was purified by washing with $200 \mathrm{ml}$ of ethanol [13].

\section{Extraction of sweet potato starch}

The fresh sweet potato tubers were washed and peeled using a stainless steel knife. Peeled sweet potatoes were grinded and passed through a sieve of diameter $150 \mu \mathrm{m}$. The slurry was allowed to sediment for $3 \mathrm{~h}$. 
The supernatant liquid was then decanted and allowed to sediment. The sediment was treated with $0.1 \mathrm{~N} \mathrm{NaOH}$ to precipitate the protein content of starch. Extracted starch was air dried [14].

Extraction of fenugreek gum

One hundred grams of fenugreek seeds were coarsely grounded and $1500 \mathrm{ml}$ of distilled water was added and then soaked for $12 \mathrm{~h}$. Later, it boiled for 30 min with constant stirring. Then, it was passed through a muslin cloth, and filtrate was collected. Using a muslin cloth, the mucilage was separated and washed with acetone [15].

\section{Extraction of ispaghula gum}

Ispaghula seeds were taken in a beaker and to it, 10-20 times water was added and allowed to stand for $15 \mathrm{~h}$. Solution was passed through a muslin cloth. Mucilage was precipitated with 3 volumes of $95 \%$ ethanol. Washed for 2 or 3 times with ethanol, and dried in an oven at $50^{\circ} \mathrm{C}[16,17]$

\section{Formulation of losartan potassium IR tablets}

The IR granules of losartan potassium were prepared by wet granulation technique [18]. Fenugreek gum, sweet potato starch, and ispaghula gum were used as natural disintegrants. The composition of tablets was shown in Table 1.

\section{Formulation of SR tablets metformin $\mathrm{HCl}$}

The SR granules of metformin hydrochloride were prepared by wet granulation technique. Guar gum, xanthan gum, and pectin were used as release retardants to control the drug release for a prolonged period of time [19]. The formulations of tablets were shown in Table 2.

\section{Bilayer tablets of losartan potassium and metformin hydrochloride} Optimized IR granules of losartan potassium (L4) + SR granules of metformin hydrochloride were (F2) fed in to separate hoppers of the bilayer tablet compression machine (Cadmach, Ahmedabad). Single compression of SR granules was done followed by the filing of IR granules on SR layer [20]. Finally, compression of IR layer over SR layer resulting in the formation of bilayer tablets.

\section{Pre-formulation studies}

Fourier transform infrared spectroscopy study was conducted to identify the purity of drug and test the compatibility of drug with excipients.

\section{Evaluation of plane and bilayer tablets \\ Calibration curve}

For losartan potassium

One hundred milligrams of drug were weighed and transferred to a $100 \mathrm{ml}$ standard flask and made up to volume using $0.1 \mathrm{~N} \mathrm{HCl}$. Ten milliliters of stock solution were pipetted out in a separate $100 \mathrm{ml}$ standard flask and volume was made up using $0.1 \mathrm{~N} \mathrm{HCl}$. From resulting solution, $2,4,6,8$, and $10 \mathrm{ml}$ were pipetted out in a separate $100 \mathrm{ml}$ standard flasks and made up to volume using $0.1 \mathrm{~N} \mathrm{HCl}$ to represent $2,4,6,8$, and $10 \mu \mathrm{g} / \mathrm{ml}$ of the drug. The absorbance of the solution was measured at $205 \mathrm{~nm}$, taking $0.1 \mathrm{~N} \mathrm{HCl}$ as blank using ultraviolet (UV)-visible spectrophotometer [21,22]. The calibration curve was then plotted, taking concentration $(\mu \mathrm{g} / \mathrm{ml})$ along $X$-axis and absorbance along Y-axis. It was shown in Fig. 1.

\section{For metformin hydrochloride}

One hundred milligrams of drug were weighed and transferred to a $100 \mathrm{ml}$ standard flask and made up to volume using $0.1 \mathrm{~N} \mathrm{HCl}$. Ten milliliters of the stock solution were pipetted out in separate $100 \mathrm{ml}$ standard flask and volume was made up to volume using a buffer. From the resulting solution, 2, 4, 6, 8, and $10 \mathrm{ml}$ were pipetted out in a separate $100 \mathrm{ml}$ standard flasks and made up to volume using $0.1 \mathrm{~N} \mathrm{HCl}$ to represent $2,4,6,8$, and $10 \mu \mathrm{g} / \mathrm{ml}$ of the drug. The absorbance of the solutions was measured at $233 \mathrm{~nm}$, taking $0.1 \mathrm{~N} \mathrm{HCl}$ as blank using a UV-visible spectrophotometer. The same procedure was repeated using a 6.8 phosphate buffer solution as a solvent. The calibration curve was then plotted, taking concentration $(\mu \mathrm{g} / \mathrm{ml})$ along X-axis and absorbance along Y-axis. It was shown in Fig. 2.

\section{Uniformity of weight}

Twenty tablets are randomly selected and weighed individually, then the average weight is calculated from the total weight of tablets.

Table 1: Composition of IR tablets of losartan

\begin{tabular}{|c|c|c|c|c|c|c|}
\hline Ingredients & L1 & $\mathbf{L} 2$ & L3 & L4 & L5 & L6 \\
\hline Losartan & $50 \mathrm{mg}$ & $50 \mathrm{mg}$ & $50 \mathrm{mg}$ & $50 \mathrm{mg}$ & $50 \mathrm{mg}$ & $50 \mathrm{mg}$ \\
\hline \multicolumn{7}{|l|}{ Potassium } \\
\hline Lactose & $80 \mathrm{mg}$ & $75 \mathrm{mg}$ & $80 \mathrm{mg}$ & $75 \mathrm{mg}$ & $80 \mathrm{mg}$ & $75 \mathrm{mg}$ \\
\hline Starch & $55 \mathrm{mg}$ & $55 \mathrm{mg}$ & $55 \mathrm{mg}$ & $55 \mathrm{mg}$ & $55 \mathrm{mg}$ & $55 \mathrm{mg}$ \\
\hline PVP K 30 & $5 \mathrm{mg}$ & $5 \mathrm{mg}$ & $5 \mathrm{mg}$ & $5 \mathrm{mg}$ & $5 \mathrm{mg}$ & $5 \mathrm{mg}$ \\
\hline Fenugreek gum & $5 \mathrm{mg}$ & $10 \mathrm{mg}$ & - & - & - & - \\
\hline Ispaghula gum & - & - & $5 \mathrm{mg}$ & $10 \mathrm{mg}$ & - & - \\
\hline Magnesium stearate & $2.5 \mathrm{mg}$ & $2.5 \mathrm{mg}$ & $2.5 \mathrm{mg}$ & $2.5 \mathrm{mg}$ & $2.5 \mathrm{mg}$ & $2.5 \mathrm{mg}$ \\
\hline talc & $2.5 \mathrm{mg}$ & $2.5 \mathrm{mg}$ & $2.5 \mathrm{mg}$ & $2.5 \mathrm{mg}$ & $2.5 \mathrm{mg}$ & $2.5 \mathrm{mg}$ \\
\hline Total wt & $200 \mathrm{mg}$ & $200 \mathrm{mg}$ & $200 \mathrm{mg}$ & $200 \mathrm{mg}$ & $200 \mathrm{mg}$ & $200 \mathrm{mg}$ \\
\hline
\end{tabular}

IR: Immediate release

Table 2: Composition of SR metformin hydrochloride tablets

\begin{tabular}{|c|c|c|c|c|c|c|c|c|c|}
\hline Ingredients & F1 & F2 & F3 & F4 & F5 & F6 & F7 & F8 & F9 \\
\hline Metformin $\mathrm{HCl}$ & $500 \mathrm{mg}$ & $500 \mathrm{mg}$ & $500 \mathrm{mg}$ & $500 \mathrm{mg}$ & $500 \mathrm{mg}$ & $500 \mathrm{mg}$ & $500 \mathrm{mg}$ & $500 \mathrm{mg}$ & $500 \mathrm{mg}$ \\
\hline Guar gum & $100 \mathrm{mg}$ & $150 \mathrm{mg}$ & $200 \mathrm{mg}$ & - & - & - & - & - & - \\
\hline Xanthan gum & - & - & - & $100 \mathrm{mg}$ & $150 \mathrm{mg}$ & $200 \mathrm{mg}$ & - & - & - \\
\hline Pectin & - & - & - & - & - & - & $100 \mathrm{mg}$ & $150 \mathrm{mg}$ & $200 \mathrm{mg}$ \\
\hline Lactose & $160 \mathrm{mg}$ & $110 \mathrm{mg}$ & $60 \mathrm{mg}$ & $160 \mathrm{mg}$ & $110 \mathrm{mg}$ & $60 \mathrm{mg}$ & $160 \mathrm{mg}$ & $110 \mathrm{mg}$ & $60 \mathrm{mg}$ \\
\hline PVP K30 & $30 \mathrm{mg}$ & $30 \mathrm{mg}$ & $30 \mathrm{mg}$ & $30 \mathrm{mg}$ & $30 \mathrm{mg}$ & $30 \mathrm{mg}$ & $30 \mathrm{mg}$ & $30 \mathrm{mg}$ & $30 \mathrm{mg}$ \\
\hline Isopropyl alcohol & q. s & q. s & q. $s$ & q. s & q. s & q. $s$ & q. $s$ & q. $s$ & q. s \\
\hline Talc & $5 \mathrm{mg}$ & $5 \mathrm{mg}$ & $5 \mathrm{mg}$ & $5 \mathrm{mg}$ & $5 \mathrm{mg}$ & $5 \mathrm{mg}$ & $5 \mathrm{mg}$ & $5 \mathrm{mg}$ & $5 \mathrm{mg}$ \\
\hline Total wt & $800 \mathrm{mg}$ & $800 \mathrm{mg}$ & $800 \mathrm{mg}$ & $800 \mathrm{mg}$ & $800 \mathrm{mg}$ & $800 \mathrm{mg}$ & $800 \mathrm{mg}$ & $800 \mathrm{mg}$ & $800 \mathrm{mg}$ \\
\hline
\end{tabular}

SR: Sustained release, $\mathrm{HCl}$ : Hydrochloride layer 


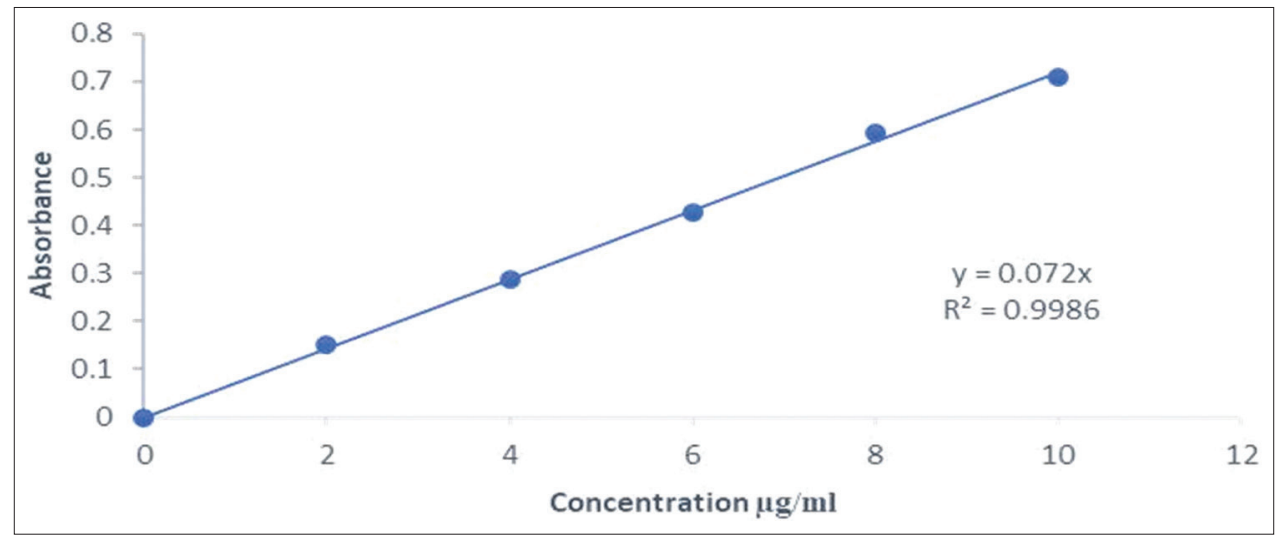

Fig. 1: Calibration curve of losartan potassium in $0.1 \mathrm{~N}$ hydrochloride layer

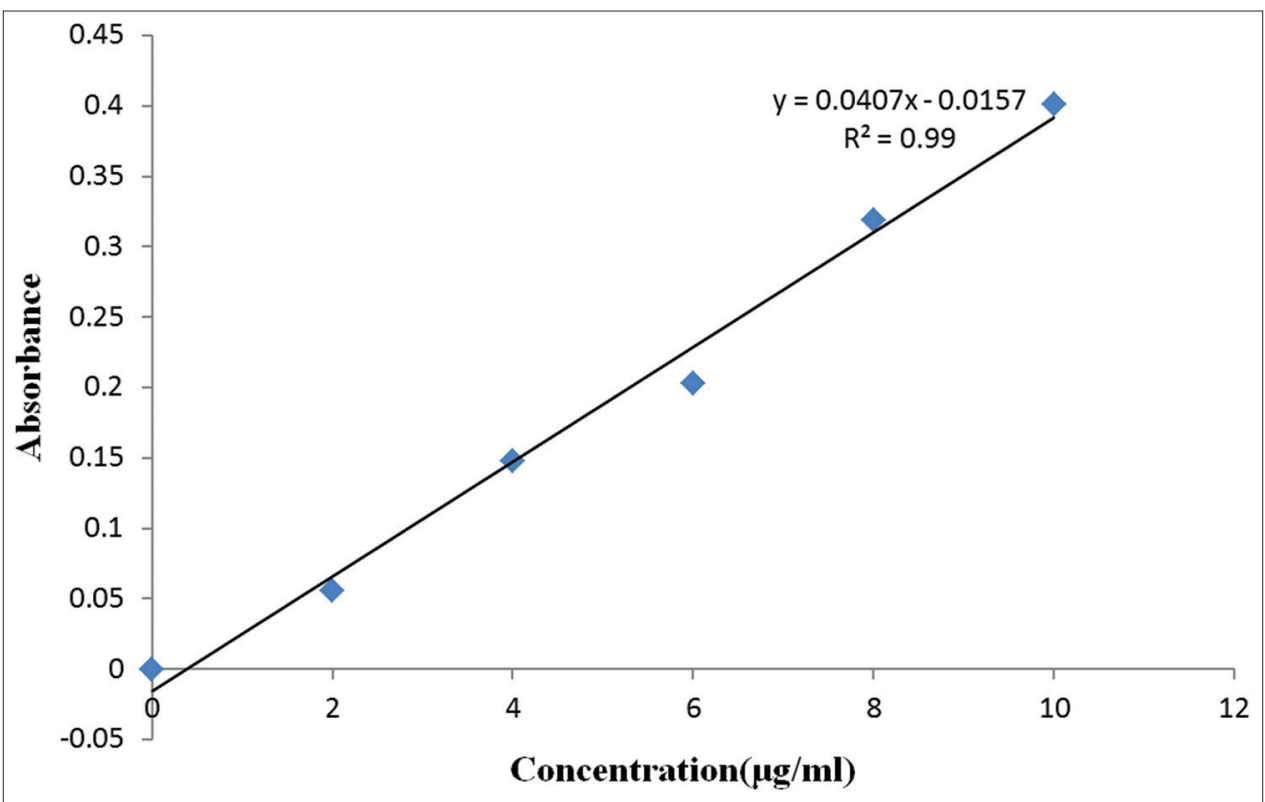

Fig. 2: Calibration curve of metformin hydrochloride in $6.8 \mathrm{pH}$ phosphate buffer

Individual weights are compared with average weight. The percentage difference in weight variation should be within limits.

\section{Hardness test}

Five tablets were randomly selected from each formulation and the pressure at which each tablet crushed was recorded.

\section{Thickness}

Five tablets were randomly selected and thickness measured using Vernier Calipers.

\section{Friability}

Ten tablets were initially weighed and transferred into friabilator. The friabilator was operated at $25 \mathrm{rpm}$ for 100 revolutions. The tablets were weighed and percentage friability was then calculated [23].

\section{Drug content}

Simultaneous estimation of both drugs was carried out using a UVvisible spectrophotometer.

Preparation of standard stock solution of losartan potassium: Losartan potassium equivalent to $50 \mathrm{mg}$ was accurately weighed and $50 \mathrm{ml}$ of $0.1 \mathrm{~N} \mathrm{HCl}$ was added and sonicated for $10 \mathrm{~min}$. The volume was made up to $100 \mathrm{ml}$ with buffer and $2 \mathrm{ml}$ of the solution was diluted with $100 \mathrm{ml} 0.1 \mathrm{~N} \mathrm{HCl}$.
Preparation of standard stock solution of metformin hydrochloride: Metformin hydrochloride equivalent to $50 \mathrm{mg}$ was taken and $50 \mathrm{ml}$ of $0.1 \mathrm{~N} \mathrm{HCl}$ was added and sonicated for $10 \mathrm{~min}$. The volume was made up to $100 \mathrm{ml}$ with buffer and $2 \mathrm{ml}$ of the solution was diluted with $100 \mathrm{ml}$ of $0.1 \mathrm{~N} \mathrm{HCl}$

Preparation of sample solution: Twenty tablets were accurately weighed and then ground to a fine powder. One hundred milligrams of the powder were weighed and dissolved in $0.1 \mathrm{~N} \mathrm{HCl}$ and then sonicated. The volume was made up to $100 \mathrm{ml}$ with $0.1 \mathrm{~N} \mathrm{HCl}$. Two milligrams of the solution were diluted with $0.1 \mathrm{~N} \mathrm{HCl}$. The absorbance of the resulting solution was measured at $205 \mathrm{~nm}$ and $233 \mathrm{~nm}$, respectively. The amount of both the drugs was determined.

\section{Disintegration}

The disintegration test for IR tablet was performed by placing one tablet in each six tubes and to maintain temperature of disintegration media at $37^{\circ} \mathrm{C}$ and disintegrating time was noted.

\section{In-vitro dissolution}

For IR tablets

Dissolution studies of losartan potassium tablets were carried out using USP type II (paddle) dissolution apparatus, for a period of $30 \mathrm{~min}$. Nine hundred milliliters of $0.1 \mathrm{~N} \mathrm{HCl}$ were used as dissolution medium at a temperature of $37^{\circ} \mathrm{C} \pm 0.5^{\circ} \mathrm{C}$. The paddle was stirred at a 
speed of $100 \mathrm{rpm}$ [23]. The absorbance of the solution was measured at $205 \mathrm{~nm}$, taking $0.1 \mathrm{~N} \mathrm{HCl}$ as a blank solution using a UV-visible spectrophotometer.

\section{For SR tablets}

Dissolution studies of metformin hydrochloride tablets were carried out using USP type II (paddle) dissolution apparatus. For the first $2 \mathrm{~h}, 900 \mathrm{ml}$ of $0.1 \mathrm{~N} \mathrm{HCl}$ was used as a dissolution medium followed by $900 \mathrm{ml}$ of 6.8 phosphate buffer solution for the next $8 \mathrm{~h}$ at a temperature of $37^{\circ} \mathrm{C} \pm 0.5^{\circ} \mathrm{C}$. The paddle was stirred at a speed of $100 \mathrm{rpm}$. The absorbance of the solution was measured at $233 \mathrm{~nm}$, taking pH 6.8 phosphate buffer as a blank solution using UV-visible spectrophotometer.

\section{For bilayer tablets}

The in-vitro dissolution was carried out using USP dissolution testing apparatus type II. The tablets were placed in $0.1 \mathrm{~N} \mathrm{HCl}$ for the first $2 \mathrm{~h}$ and $\mathrm{pH} 6.8$ phosphate buffer for the next $8 \mathrm{~h}$. The apparatus was maintained at temperature $37^{\circ} \mathrm{C}$ and $50 \mathrm{rpm}$ rotating speed was maintained. Five milliliters of aliquots were withdrawn and replaced with fresh dissolution medium maintained at the same temperature. Samples were analyzed using a UV spectrophotometer.

\section{In vitro release kinetics}

Data obtained from the in-vitro dissolution study of the optimized bilayer tablets were used to study in vitro release kinetics by plotting in various release rate kinetic models [23].

\section{RESULTS AND DISCUSSION}

The present study was to develop bilayer tablets containing losartan potassium for IR and metformin hydrochloride for SR for diabetic patients having hypertension and to provide effective, safe, and stable pharmaceutical formulation.

Different natural gums, namely, guar gum, xanthan gum, pectin, are used for SR [19] formulations. Fenugreek gum, ispaghula gum, and sweet potato gum are used as disintegrants [15] in IR formulation.
The selected polymers were evaluated for drug and excipient compatibility by performing Fourier-transform infrared studies. There were no interactions of drugs with excipients. The results were indicated in Figs. 3-6.

\section{Preparation of IR tablets}

Preliminary tablets were done by varying polymer content to study the influence of polymer on drug release.

The IR granules of losartan potassium with $2.5 \%$ and $5 \%$ concentrations of fenugreek gum, ispaghula gum, and sweet potato starch were formulated into six formulations L1-L6 which were given in Table 1. These tablets were subjected to weight variation, hardness friability, and disintegration, drug content. The values were shown in Table 3 . The IR tablets disintegrated quickly due to the use of natural super disintegrants. All the four natural gums used decreases the disintegration time of tablet and can be effectively employed in fast dispersing tablets. As ispaghula gum affects the (decreases) disintegration time (by increasing the wetting) that depends upon pore size [24] of the inner surface of tablets. The gum acts as a natural super disintegrant due to its excellent swelling and wetting characteristics.

A comparison of percentage cumulative drug release of six IR Losartan potassium tablets is given in Fig. 7a. The formulation containing ispaghula gum $5 \%$ concentration exhibited superior drug release profile compared to remaining formulations. Hence, L4 formulation was selected to design bilayer tablets.

\section{Preparation of SR tablets}

The SR granules of metformin hydrochloride with varying concentrations of $12.55 \%, 18.75 \%$, and $25 \%$ of guar gum, xanthan gum, and pectin were formulated into nine formulations F1-F9 which were given in Table 2. All the tablets formulated were within the specified limits. They have passed the official tests. Their values were shown in Table 4.

The results of in vitro dissolution study of metformin hydrochloride SR tablets using $0.1 \mathrm{~N} \mathrm{HCl}$ at first $2 \mathrm{~h}$ and $6.8 \mathrm{pH}$ phosphate buffer for next $8 \mathrm{~h}$ showed that the formulation F1 showed complete release of

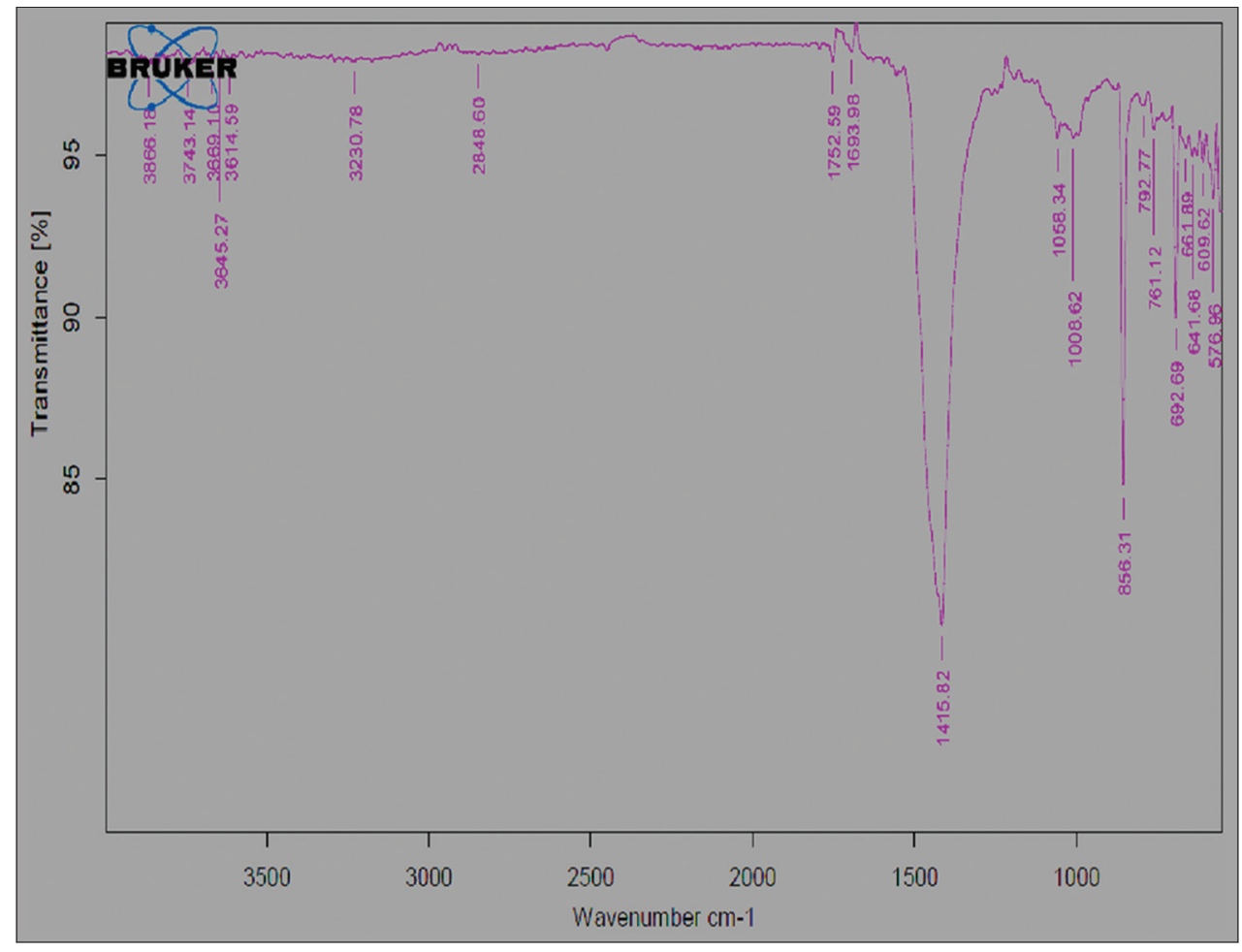

Fig. 3: Fourier-transform infrared of losartan potassium 


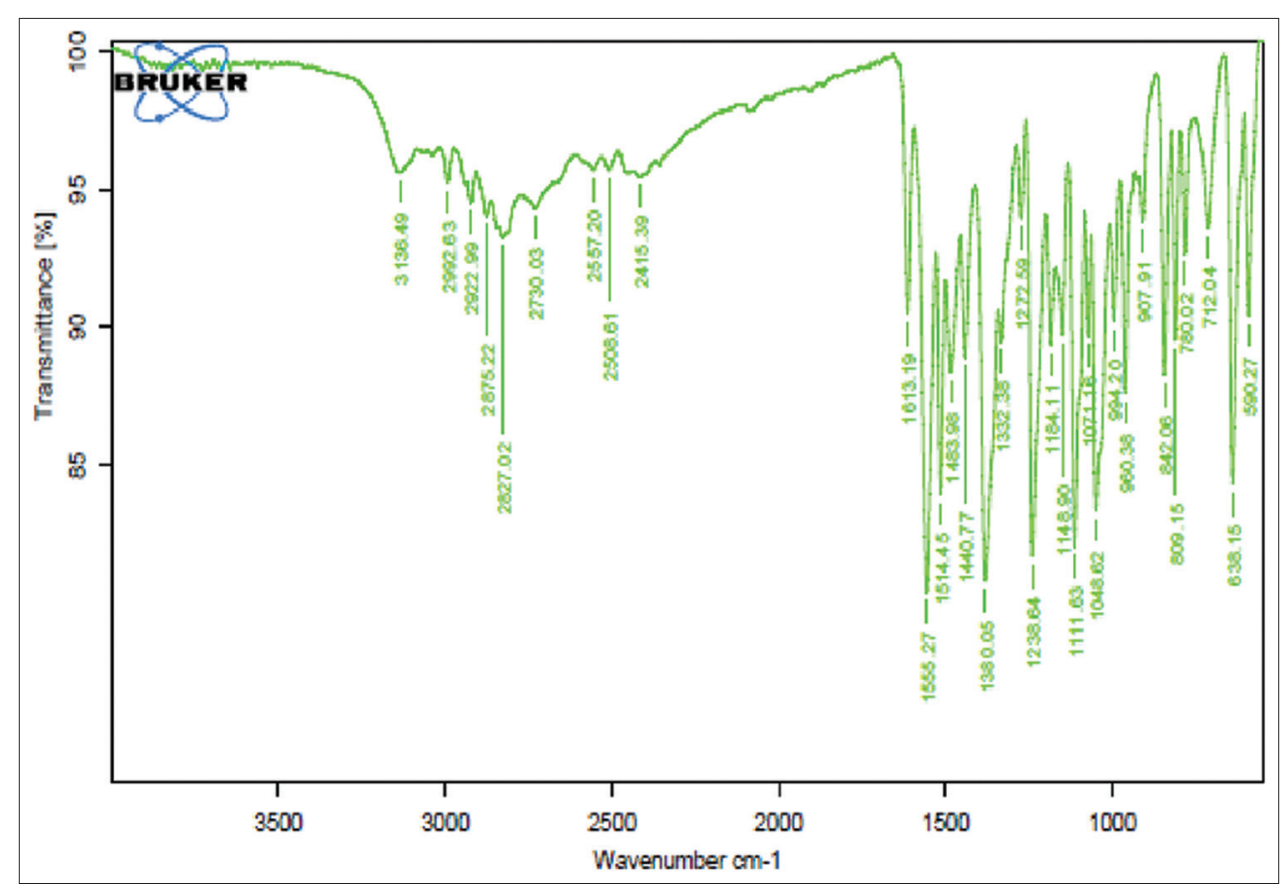

Fig. 4: Fourier-transform infrared of metformin hydrochloride layer

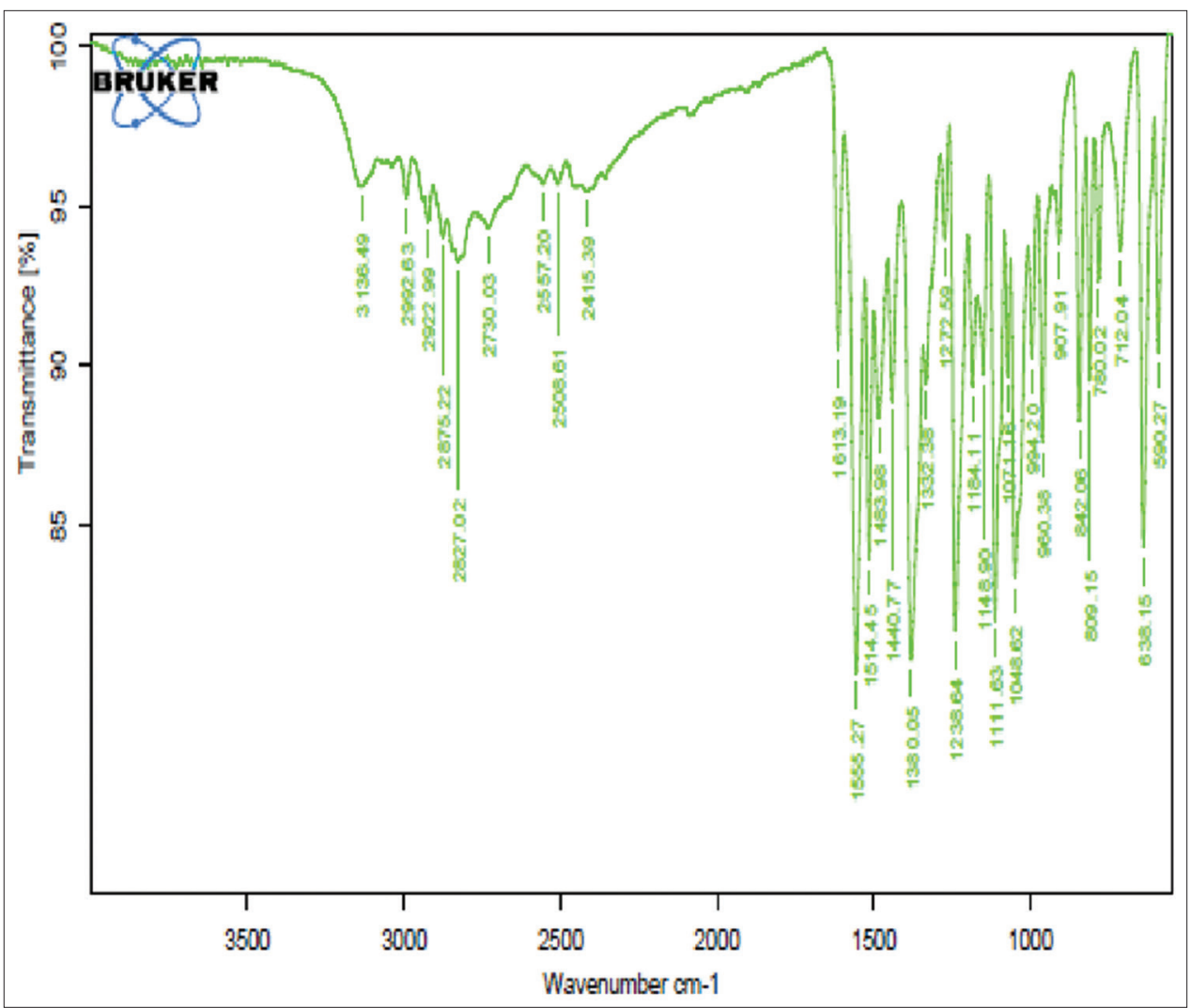

Fig. 5: Fourier-transform infrared of losartan and fenugreek gum

$98.69 \%$ of drug release at $7 \mathrm{~h}$ period of time, but it does not meet the IP specifications. In formulation F2 containing $150 \mathrm{mg}$ guar gum showed SR drug release of $97.16 \%$ and met IP specifications. A comparison of percentage drug release of SR metformin hydrochloride formulations was depicted in Fig. 7b. Based on the release, formulation F2 was selected for the final preparation of bilayer tablets. The remaining formulations were not selected for bilayer tablets since; those were not meeting the desired drug release standards.

\section{Bilayer tablet evaluation}

The compressed bilayer tablets were evaluated for uniformity of weight, thickness, hardness, friability, and drug content and the results are shown in Table 5. The results were within the specified limits.

\section{In-vitro dissolution}

The bilayer tablet showed the $98.73 \%$ release of losartan potassium in $30 \mathrm{~min}$ given in Fig. 15. The tablet released $31.42 \%$ of metformin 


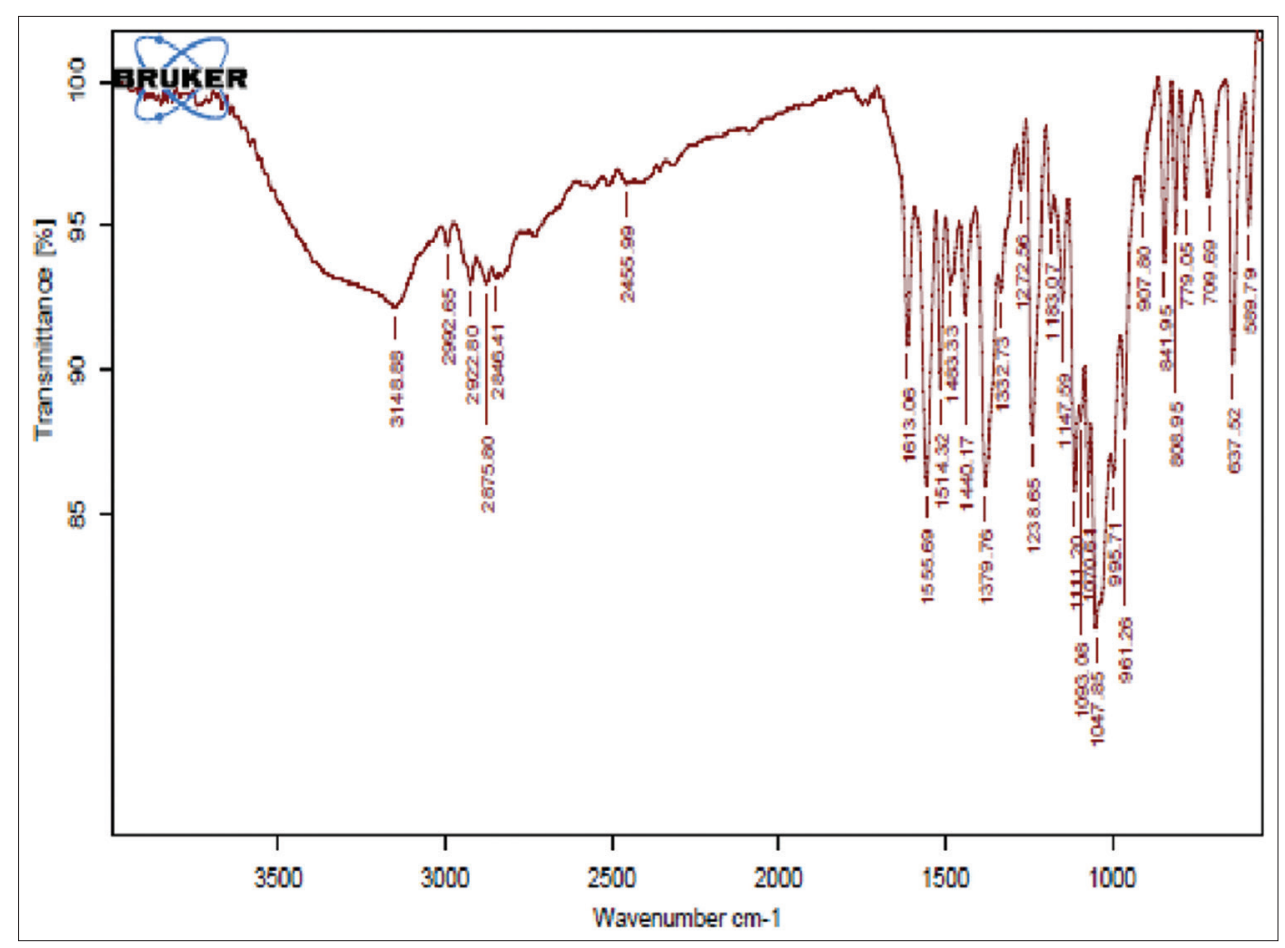

Fig. 6: Fourier-transform infrared of metformin and guar gum

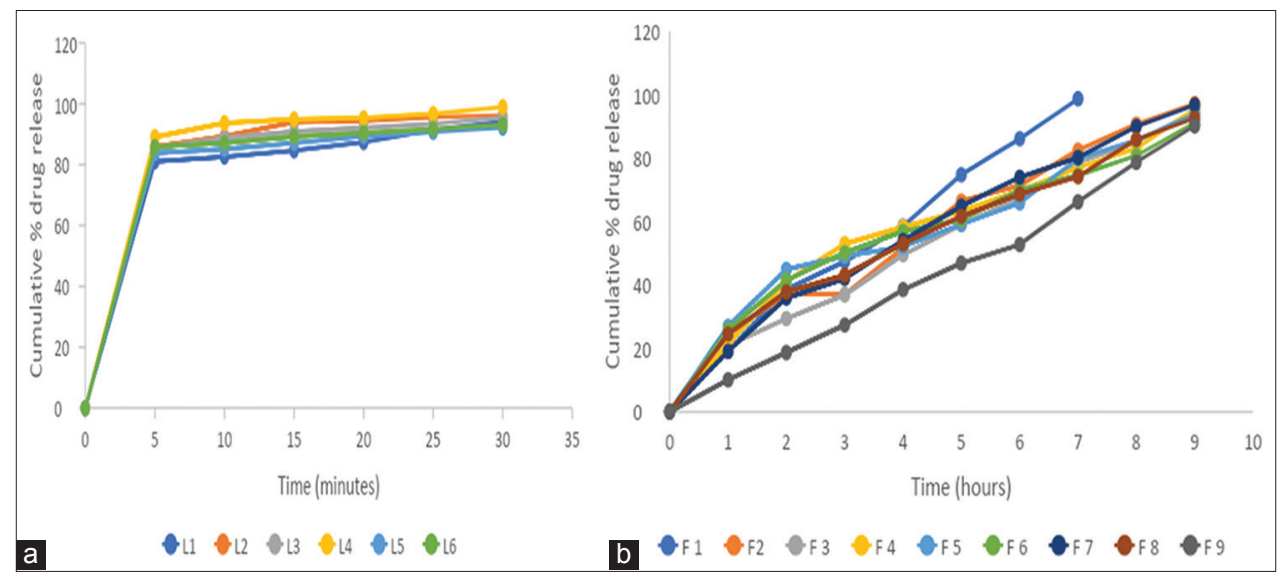

Fig. 7: (a) Comparison of cumulative \% drug release of six immediate release losartan potassium tablets (b) comparison of cumulative \% drug release of SR tablets of metformin $\mathrm{HCl}$

Table 3: Evaluation tests for IR losartan potassium tablets

\begin{tabular}{|c|c|c|c|c|c|}
\hline Formulation & $\begin{array}{l}\text { Uniformity of weight (mg) } \\
(M e a n \pm S D)(n=20)\end{array}$ & $\begin{array}{l}\text { Hardness }\left(\mathrm{kg} / \mathrm{cm}^{2}\right) \\
(\text { Mean } \pm \text { SD) }(\mathrm{n}=5)\end{array}$ & $\begin{array}{l}\text { \%friability (Mean } \pm \text { SD) } \\
(n=5)\end{array}$ & $\begin{array}{l}\text { \%drug content } \\
(M e a n \pm S D)(n=5)\end{array}$ & $\begin{array}{l}\text { Disintegration time }(\mathrm{min}) \\
(\text { Mean } \pm \text { SD) }(n=6)\end{array}$ \\
\hline L1 & $200.1 \pm 0.984$ & $2.98 \pm 0.31$ & $0.078 \pm 0.008$ & $96.81 \pm 0.93$ & 10 \\
\hline L2 & $199.3 \pm 0.655$ & $3.15 \pm 0.25$ & $0.094 \pm 0.005$ & $98.33 \pm 0.103$ & 6 \\
\hline L3 & $199.0 \pm 0.908$ & $3.11 \pm 0.48$ & $0.087 \pm 0.06$ & $97.31 \pm 0.54$ & 7 \\
\hline L4 & $200.6 \pm 0.678$ & $3.24 \pm 0.16$ & $0.185 \pm 0.005$ & $99.21 \pm 0.117$ & 4 \\
\hline L5 & $199.2 \pm 0.721$ & $2.94 \pm 0.39$ & $0.074 \pm 0.02$ & $98.23 \pm 0.738$ & 11 \\
\hline L6 & $198.6 \pm 0.546$ & $3.08 \pm 0.51$ & $0.164 \pm 0.003$ & $97.21 \pm 0.217$ & 8 \\
\hline
\end{tabular}

IR: Immediate release

hydrochloride in $2 \mathrm{~h}$ and $96.36 \%$ of metformin hydrochloride at the end of $10 \mathrm{~h}$ given in Fig. 8. The slow release of metformin $\mathrm{HCl}$ was due to the use of guar gum as SR polymer. Guar gum has exhibited sustained drug release characteristics due to the formation of a matrix around the surface of the tablet that undergoes drug diffusion, as reported earlier [19]. The drug release of bilayer formulation was within pharmacopoeial limits.
In-vitro release kinetics

The results obtained from in vitro dissolution studies were fitted in various kinetic models. The bilayer tablet followed zero-order release kinetics. The optimized formulation followed Fickian diffusion-based on n-value, as shown in Table 6. The rate of drug release is independent of the drug concentration in the formulation. 
Table 4: Evaluation tests for metformin HCl SR tablet

\begin{tabular}{lllll}
\hline Formulation & $\begin{array}{l}\text { Uniformity of weight }(\mathbf{m g}) \\
\text { (Mean } \pm \text { SD) }\end{array}(\mathbf{n = 2 0})$ & $\begin{array}{l}\text { Hardness }\left(\mathbf{k g} / \mathbf{c m}^{2}\right) \\
\text { (Mean } \pm \text { SD) } \mathbf{( n = 5 )}\end{array}$ & $\begin{array}{l}\text { \%friability } \\
\text { (Mean } \pm \text { SD) }(\mathbf{n}=5)\end{array}$ & $\begin{array}{l}\text { Drug content } \\
\text { (Mean } \pm \text { SD) }(\mathbf{n}=5)\end{array}$ \\
\hline F1 & $797 \pm 0.96$ & $4.08 \pm 0.013$ & 0.019 & 98.69 \\
F2 & $790 \pm 1.17$ & $4.98 \pm 0.105$ & 0.021 & 99.86 \\
F3 & $793 \pm 3.68$ & $4.12 \pm 0.009$ & 0.024 & 99.51 \\
F4 & $780 \pm 0.89$ & $4.21 \pm 0.113$ & 0.029 & 97.53 \\
F5 & $799 \pm 0.91$ & $4.10 \pm 0.005$ & 0.032 & 99.79 \\
F6 & $798 \pm 0.15$ & $4.06 \pm 0.006$ & 0.030 & 98.90 \\
F7 & $796 \pm 1.12$ & $4.18 \pm 0.004$ & 0.028 & 99.83 \\
F8 & $801 \pm 2.63$ & $4.13 \pm 0.102$ & 0.025 & 99.39 \\
F9 & $798 \pm 3.18$ & $4.16 \pm 0.132$ & 0.033 & 98.73 \\
\hline
\end{tabular}

SR: Sustained release, HCl: Hydrochloride layer

Table 5: Evaluation tests for bilayer tablets

\begin{tabular}{llllll}
\hline $\begin{array}{l}\text { Uniformity of weight }(\mathrm{g}) \\
(\text { Mean } \pm \mathbf{S D})(\mathbf{n}=\mathbf{2 0})\end{array}$ & $\begin{array}{l}\text { Thickness }(\mathbf{m m}) \\
(\text { Mean } \pm \mathbf{S D})(\mathbf{n}=\mathbf{5})\end{array}$ & $\begin{array}{l}\text { Hardness }\left(\mathbf{k g} / \mathbf{c m}^{2}\right) \\
(\text { Mean } \pm \mathbf{S D})(\mathbf{n}=\mathbf{5})\end{array}$ & $\begin{array}{l}\text { Friability \% } \\
(\text { Mean } \pm \mathbf{S D})(\mathbf{n}=\mathbf{5})\end{array}$ & $\begin{array}{l}\text { Disintegration time for IR } \\
\text { layer }(\mathbf{M e a n} \pm \mathbf{S D})(\mathbf{n}=\mathbf{6})\end{array}$ & $\begin{array}{l}\text { Drug content }(\%) \\
(\mathbf{M e a n} \pm \mathbf{S D})(\mathbf{n}=\mathbf{5})\end{array}$ \\
\hline $1.061 \pm 0.0064$ & $5.98 \pm 0.0042$ & $7.0 \pm 0.0056$ & $0.16 \pm 0.0011$ & 4 min $50 \mathrm{~s}$ & $\begin{array}{l}\text { Losartan potassium } \\
96.63 \pm 0.1700 \\
\end{array}$ \\
& & & & & Metformin \\
& & & & $98.27 \pm 0.23$ \\
\hline
\end{tabular}

IR: Immediate release

Table 6: In vitro release kinetics of bilayer tablet

\begin{tabular}{|c|c|c|c|c|c|c|}
\hline Zero order (r) & First order (r) & Higuchi (r) & Peppas (r) & $t_{50 \%}(h)$ & $\mathbf{t}_{90 \%}(\mathbf{h})$ & $K\left(\mathbf{h}^{-1}\right)$ \\
\hline 0.986 & 0.885 & 0.975 & 0.978 & 5.023 & 9.041 & 8.529 \\
\hline
\end{tabular}

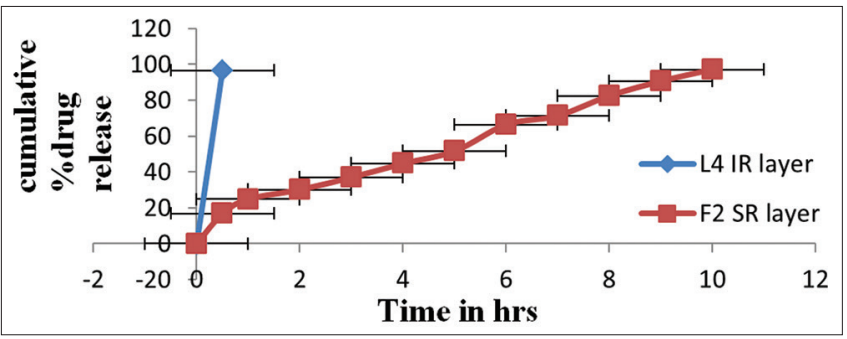

Fig. 8: Comparison of drug release in bilayer tablets

\section{CONCLUSION}

The bilayer tablets designed for multiple drug therapy, that is, both diabetes and hypertension, can be effectively delivered using ispaghula gum and guar gum. The drugs losartan potassium and metformin $\mathrm{HCl}$ were delivered effectively by this approach.

\section{ACKNOWLEDGMENTS}

The authors are grateful to Apogen remedies Ltd. for providing gift samples of losartan.

\section{AUTHORS' CONTRIBUTIONS}

The corresponding author has planned and designed the whole project. She was also involved in the preparation and communication of entire official article work. Author 2 was involved in experimental work.

\section{CONFLICTS OF INTEREST}

The author declares that there were no conflicts of interest.

\section{AUTHORS' FUNDING}

The authors received no financial support for research, authorship, or publication of this article. However, they were thankful to Bapatla
Education Society, Bapatla, for providing the necessary infrastructure facilities and chemicals.

\section{REFERENCES}

1. Cooper J, Gun C. Tutorial Pharmacy. $6^{\text {th }}$ ed. New Delhi: CBS Publisher and Distributors; 2004. p. 76-81.

2. Aulton ME. The Design and Manufacture of Medicines. $3^{\text {rd }}$ ed. Edinburgh: Churchill Livingstone; 2007. p. 92-6.

3. Brahmankar DM, Jaiswal SB. Biopharmaceutics and Pharmacokinetics. $1^{\text {st }}$ ed. New Delhi: Vallabh Prakashan; 1995. p. 53-61.

4. Ansel HC, Allen LV, Popovich NG. Pharmaceutical Dosage Forms and Drug Delivery Systems. $7^{\text {th }}$ ed. Baltimore: Lippincott Williams and Wilkins; 2000. p. 89-94.

5. Ballard BE. Remington's Pharmaceutical Sciences. $6^{\text {th }}$ ed. Easton, PA: Mack Publishing Company; 1990. p. 113-21.

6. Musle K, Payghan A, Disuza JI. Formulation, evaluation and development of bilayer tablet. Int J Pharm Res Dev 2011;4:80-7.

7. Tripathi KD. Essential of Medical Pharmacology. $6^{\text {th }}$ ed. New Delhi: Jaypee Brothers Medical Publishers Private Ltd.; 2008. p. 488-90.

8. Losartan. Available from: http://www.drugs.com/ppa/losartanpotassium.html. [Last accessed on 2019 Jan 18].

9. Losartan. Available from: http://www.drugbank.ca/drugg/DB00678. [Last accessed on 2019 Jan 18].

10. Metformin. Available from: http://www.drugs.com/pro/metformin. html. [Last accessed on $2019 \mathrm{Feb} 10]$.

11. Metformin. Available from: http://www.drugbank.ca/drugs/db00331. [Last accessed on $2019 \mathrm{Feb}$ 10].

12. Sheskey PJ, CookWG, Cable CG. Handbook of Pharmaceutical Excipients. $8^{\text {th }}$ ed. London: Pharmaceutical Press; 2017. p. 76-9,110-3,121-6.

13. Srivastava P, Malviya R. Sources of pectin, extraction and its applications in pharmaceutical industry-an overview. Indian J Nat Prod Resour 2011;2:10-8

14. Brabet C, Reynoso D, Mestres C, Arredondo J, Scott G. Starch Content and Properties of 106 Sweet Potato Clones from World Germplasm Collection. CIP Program Report 1997-1998. Lima, Peru: CIP Program Report; 1998.

15. Sukhavasi S, Kishore VS. Formulation and evaluation of fast dissolving tablets of amlodipine besylate by using fenugreek seed mucilage and Ocimum basilicum gum. Int Curr Pharm J 2012;6:113-9. 
16. Jeevana JB, Jyosna D. Multiparticulate drug delivery systems using natural polymers as release retardant materials. Int J Pharm Pharm Sci 2014;6:61-5.

17. Maurya DP, Sultana Y, Aqil M, Kumar D, Chuttani K, Ali A, et al. Formulation and optimization of alkaline extracted ispaghula husk microparticles of isoniazid-in vitro and in vivo assessment. J Microencapsul 2011;28:472-83.

18. Kolhe SS, Dabhade MP. Formulation and evaluation of sustained release bilayer tablets of losartan potassium. World J Pharm Pharm Sci 2018;2:276-83.

19. Babu GS, Kumar DV, Aishwarya M, Malathy PS. Formulation and in-vitro characterization of sustained release matrix tablets of metformin hydrochloride. J Glob Trends Pharm Sci 2014;2:98-109.

20. Kesharvani S, Jaiswal PK, Mukerjee A, Singh AK. Formulation and evaluation of metformin hydrochloride loaded floating microsphere. Int J Pharm Pharm Sci 2020;12:74-82.

21. Arayne MS, Sultana N, Zuberi MH, Siddiqui FA. Spectrophotometric quantitation of metformin in bulk drug and pharmaceutical formulations using multivariate technique. Indian J Pharm Sci 2009;2:96-100.

22. Kaveri K, Saravanan C, Mozhi MT. Simultaneous estimation of losartan potassium and amlodipine besylate in tablet dosage form by UV spectrophotometer. Int Res J Pharm 2011;2:96-100.

23. Ministry of Health and Family Welfare. Indian Pharmacopoeia. Ghaziabad: The Indian Pharmacopoeial Commission; 2010. p. 1607-9, 1657-9,751-4.

24. Shukla AK, Kumar M, Bishoni RS, Jain CP. Applications of fenugreek seed gum: In novel drug delivery. Asian J Biomat Res 2017;3:1-10. 